\title{
Variation in Anatomical Characteristics of Bamboo, Bambusa rigida
}

(Variasi dalam Ciri Anatomi Buluh, Bambusa rigida)

\author{
Xing-YAn HuAng, Jin-QIU QI*, JiU-LONG XIE, JiAn-Feng HaO, BAI-Dong QIN \& Si-Min Chen
}

\section{ABSTRACT}

The culms of bamboo Bambusa rigida ranging from 1,3 and 5 year old were obtained and investigated for anatomical characteristics in different ages, heights and zones in radial direction of culm wall thickness. The vascular bundles were denser and smaller at the top portion and outer zone of all age groups. No significant differences in vascular bundle frequency and size were found among the tree age groups. Metaxylem vessels did not vary significantly among ages. Fibre and parenchyma were longer in the middle portion of the height and middle zone in radial direction of culms wall. No significant differences in fibre and parenchyma length were observed in all age groups. The wall thicknesses of fibre and parenchyma were thicker in the top portion and outer zone. Furthermore, the wall thicknesses of fibre and parenchyma increased significantly from 1 to 3 year, showing that there is a maturing progress from 1 to 3 year.

Keywords: Anatomical morphologies; Bambusa rigida; fibre; parenchyma; vascular bundle

\section{ABSTRAK}

Kulm buluh Bambusa rigida berusia 1, 3 dan 5 tahun telah diperoleh dan dikaji untuk ciri anatomi pada pelbagai peringkat umur, ketinggian dan zon arah radius ketebalan dinding kulm. Berkas vaskular adalah lebih tumpat dan kecil di bahagian atas dan zon luar bagi semua peringkat umur. Tiada perbezaan yang signifikan dalam kekerapan berkas vaskular dan saiz ditemui antara kumpulan umur pokok. Sel salur metaxilem pula tidak berubah dengan ketara antara peringkat umur. Serabut dan parenkima adalah lebih panjang di bahagian tengah ketinggian dan zon tengah arah radius dinding kulm. Tiada perbezaan yang signifikan dalam panjang gentian dan parenkima diperhatikan pada sетиа peringkat umur. Ketebalan dinding serabut dan parenkima adalah lebih tebal di bahagian atas dan zon luar. Tambahan pula, ketebalan dinding serabut dan parenkima meningkat dengan ketara daripada usia 1 kepada 3 tahun, yang menunjukkan bahawa terdapat kemajuan daripada segi kematangan daripada usia 1 ke 3 tahun.

Kata kunci: Anatomi morfologi; Bambusa rigida; berkas vaskular; parenkima; serabut

\section{INTRODUCTION}

Bamboo is an important raw material for housing, bridge construction and other purposes in China. Since its high strength to weight ratio, straightness and rapid growth rate, bamboo can be regarded as the best possible alternative to replace timber in the future. Besides, bamboo contributes to the oxygenation and captures carbon dioxide of environment. Since bamboo has become the most important raw material for construction, the basic characteristics of anatomy should be researched in detail. Many investigations showed that the durability, toughness, workability and strength are associated with its anatomical properties (Espiloy 1987; 1992; Kelemwork 2009; Liese 1985; Parameswaran \& Liese 1976; Razak 1998). Furthermore, anatomical structure is the basis for understanding the physical, mechanical properties and its utilizations. For example, density and shrinkage were significantly correlated to radial/tangential ratio of vascular bundles (Abd. Latif et al. 1993). Fibre length and fibre wall thickness affect the modulus of elasticity and compression strength of bamboo culms (Abd. Latif et al. 1990) and the fibre length is also an important feature for paper industry (Abd. Latif 2001; Wangaard \& Woodson 1973).

Bambusa rigida is one of the most abundant bamboos distributed in Sichuan, China. Due to the lack of knowledge about the anatomical, physical and mechanical properties of this bamboo, $B$. rigida is not widely used in industry in China. Currently, it was only used for traditional products such as handicraft, basketry, farm tools and original construction materials, rather than high-value added products of panels. Basic properties can be used to reflect the quality of culms and suitability of different bamboo species for specific utilization. Therefore, in order to use this bamboo for various valueadded industrial applications, it was essential to evaluate anatomical properties of $B$. rigida culms. In this paper, variations in anatomical characteristics including vascular bundles frequency, vascular bundles size, metaxylem vessel lumen diameter, fibre length, fibre wall thickness, fibre lumen diameter and parenchyma length, parenchyma cell wall thickness and parenchyma lumen diameter at different ages, heights and zones in culm wall thickness were investigated. 


\section{MATERIALS AND METHODS}

\section{SUPPLY OF CULMS AND SAMPLING}

The culms of $B$. rigida of 1,3 and 5 year olds were collected from Yibin, Sichuan, China. The age of culms was estimated based on the colour of sheaths and culms surface by experienced farmers. Altogether 54 bamboo culms of each age group consisting of 18 culms were harvested. All age classes were harvested from a randomly selected clump in February 2012, considering the best time to harvest bamboo culms with a very minimum amount of starch (Abd. Razak et al. 1995; Liese 1985) and the culms were coated with wax immediately to reduce sap evaporation after being cut at $10 \mathrm{~mm}$ above the ground level. Thereafter, the culms were transported immediately to the laboratory. These culms were removed of branches and the top parts, followed by subdividing them into three portions with eight internodes for base, middle and top portions.

\section{VASCULAR BUNDLE DISTRIBUTION AND VESSEL SIZE}

Samples from middle of internodes were cut into sections of $10 \times 10 \mathrm{~mm} \times$ culms wall thickness. Sample blocks were dipped in 30\% hydrogen fluoride for 3-4 h to desilicate and washed with distilled water, then boiled in distilled water with microwave heating for 2-3 h until soften. The soften blocks were sliced into $30 \mu \mathrm{m}$ by a sliding microtome. After staining with $0.1 \%$ safranin-o within $30 \mathrm{~s}$, each section was washed with distilled water for $3 \mathrm{~min}$, then dehydrated with alcohol series of 30, 50, 70, 90, 95 and $100 \%$, each for $10 \mathrm{~min}$ and immersed in xylem for $10 \mathrm{~min}$. One drop of neutral balsam in slide centre, mount crosssection on slide, covered with a coverslip. The air-dried slides were observed under a digital camera microscope (OLYMPUS DP20). Digital images were subdivided into three equal parts across the culm wall and analyzed by wood anatomical analysis software. Frequency of vascular bundles was determined by counting the vascular bundle numbers on section images per $\mathrm{mm}^{2}$. The diameters of vascular bundles and vessels were measured in radial and tangential directions across the culm wall.

\section{FIBRE AND PARENCHYMA LENGTH}

The $B$. rigida bamboo sample blocks of $15 \times 10 \mathrm{~mm} \times$ culms wall thickness from the middle of internodes were subdivided into three equal parts across the culms wall, and then sliced into match stick size splints with one side blade. Splints were macerated using the Jeffrey's solution ( $10 \%$ chromic acid: $10 \%$ nitric acid mixtures $=1: 1)$ method. The macerated splints were washed carefully with distilled water. Macerated splints were stained with $0.1 \%$ safranin-o for a few seconds to contrast the fibre images. Little part of the stained splints was dispersed in a drop of $50 \%$ glycerol solution on a slide. Fifty complete and reasonably fibres and 50 complete parenchyma cells were selected randomly and measured for each part to evaluate fibre and parenchyma dimensions. The measurement was carried out with a digital microscope.

\section{FIBRE AND PARENCHYMA LUMEN DIAMETER AND CELL WALL THICKNESS}

Slides of cross-section were projected using microscope with digital camera at 400X magnification for determining fibre and parenchyma lumen diameter and cell wall thickness.

\section{RESULTS AND DISCUSSION}

\section{VASCULAR BUNDLE}

Vascular bundle frequency Vascular bundles of B. rigida were classified according to the classification of vascular bundles presented by Grosser and Liese (1971). The major vascular bundle in the middle zone should be categorized for type III, consisting of a central vascular strand and one fibre strand and types I and II with central vascular strand exist in the inner and outer zone, respectively. As presented in Table 1, the vascular bundle frequency of the 5 year old bamboos was a little larger compared with that of the 1 and 3 year old bamboos, however, no significant differences in vascular bundle frequency was found among the culm ages. From the base to top portion of the bamboo culm, the vascular bundle frequency showed an increasing trend, this is because of the fact that the top portion had thinner culm wall thickness (Grosser \& Liese 1971). In the radial direction, a significant decreasing trend in vascular bundle frequency was found from outer to the inner zone. For $B$. rigida, 12.72 to $27.07 \%$ of vascular bundles were located in the inner zone, 14.88 to $31.46 \%$ in the middle zone and 63.08 to $71.53 \%$ in the outer zone. For comparison, the top portion of the 3 year old bamboo culms had the highest vascular bundles $\left(6.97\right.$ bundle $\left./ \mathrm{mm}^{2}\right)$, while for the base portion of 1-year-old bamboo culms was the lowest (1.37 bundle/ $\mathrm{mm}^{2}$ ).

Vascular bundles size Vascular bundle size was measured as radial/tangential ratio in this study (Table 1). The results showed that the difference in vascular bundle size was not significant among the age groups. However, the vascular bundle size showed decreasing trend from the base to top portion of all the age groups. This finding is well in agreement with the reports of Abd. Latif et al. (1993), Grosser and Liese (1971) and Kelemwork (2009). The smaller vascular bundle size located in the top portion may be because of the tapering structure of culms (Abd. Latif \& Mohd. Tamizi 1992). In the radical direction, the size of vascular bundle decreased significantly form inner to outer zone. This result was similar to those of Gigantochloa scortechinii and Fargesia yunnanensis bamboos (Hisham et al. 2006; Wang et al. 2011). According to Liese (1985), smaller vascular bundles are denser in distribution than that of bigger ones, resulting in the higher density and mechanical strength for the outer zone than both inner and middle. 
TABLE 1. Mean frequency and radial/tangential ratio of vascular bundle

\begin{tabular}{ccccc}
\hline Vascular bundle frequency $\left(\right.$ No. $\left.\mathrm{mm}^{-2}\right)$ & Zone & 1 years & 3 years $^{\mathrm{a}}$ & 5 years $^{\mathrm{a}}$ \\
\hline Base & inner & $1.37 \pm 0.29^{\mathrm{a}}$ & $1.39 \pm 0.22^{\mathrm{a}}$ & $1.44 \pm 0.27^{\mathrm{a}}$ \\
& middle & $1.50 \pm 0.52^{\mathrm{a}}$ & $1.53 \pm 0.16^{\mathrm{a}}$ & $1.73 \pm 0.25^{\mathrm{a}}$ \\
& outer & $7.21 \pm 1.07^{\mathrm{b}}$ & $7.04 \pm 0.44^{\mathrm{b}}$ & $7.24 \pm 0.73^{\mathrm{b}}$ \\
& means & $3.36 \pm 3.33^{\mathrm{a}}$ & $3.32 \pm 3.22^{\mathrm{a}}$ & $3.47 \pm 3.27^{\mathrm{a}}$ \\
& inner & $1.92 \pm 0.39^{\mathrm{a}}$ & $1.92 \pm 0.30^{\mathrm{a}}$ & $1.86 \pm 0.32^{\mathrm{a}}$ \\
& middle & $2.36 \pm 0.41^{\mathrm{a}}$ & $2.53 \pm 0.34 \mathrm{a}$ & $2.39 \pm 0.44^{\mathrm{a}}$ \\
& outer & $10.32 \pm 1.07^{\mathrm{b}}$ & $10.06 \pm 0.79^{\mathrm{b}}$ & $10.37 \pm 0.93^{\mathrm{b}}$ \\
& means & $4.87 \pm 4.73^{\mathrm{a}}$ & $4.84 \pm 4.54^{\mathrm{a}}$ & $4.87 \pm 4.78^{\mathrm{a}}$ \\
& inner & $2.70 \pm 0.35^{\mathrm{a}}$ & $3.57 \pm 0.43^{\mathrm{a}}$ & $3.16 \pm 0.22^{\mathrm{a}}$ \\
& middle & $3.27 \pm 0.41^{\mathrm{a}}$ & $4.15 \pm 0.34^{\mathrm{a}}$ & $4.03 \pm 0.24^{\mathrm{a}}$ \\
& outer & $14.13 \pm 1.28^{\mathrm{b}}$ & $13.19 \pm 0.43^{\mathrm{b}}$ & $13.18 \pm 1.09^{\mathrm{b}}$ \\
& means & $6.70 \pm 6.44^{\mathrm{a}}$ & $6.97 \pm 5.40^{\mathrm{a}}$ & $6.79 \pm 5.56^{\mathrm{a}}$ \\
\hline Radial/tangential ratio of vascular bundle & Zone & 1 years & 3 years & $5 \mathrm{years}^{\mathrm{a}}$ \\
\hline Base & inner & $0.68 \pm 0.03^{\mathrm{a}}$ & $0.65 \pm 0.01^{\mathrm{a}}$ & $0.67 \pm 0.04^{\mathrm{a}}$ \\
& middle & $1.43 \pm 0.12^{\mathrm{b}}$ & $1.33 \pm 0.05^{\mathrm{b}}$ & $1.32 \pm 0.06^{\mathrm{b}}$ \\
& outer & $1.73 \pm 0.08^{\mathrm{c}}$ & $1.74 \pm 0.26^{\mathrm{c}}$ & $1.58 \pm 0.13^{\mathrm{c}}$ \\
& means & $1.28 \pm 0.54^{\mathrm{a}}$ & $1.24 \pm 0.55^{\mathrm{a}}$ & $1.19 \pm 0.47^{\mathrm{a}}$ \\
& inner & $0.67 \pm 0.05^{\mathrm{a}}$ & $0.64 \pm 0.02^{\mathrm{a}}$ & $0.65 \pm 0.01^{\mathrm{a}}$ \\
Middle & middle & $1.46 \pm 0.11^{\mathrm{b}}$ & $1.33 \pm 0.06^{\mathrm{b}}$ & $1.32 \pm 0.10^{\mathrm{b}}$ \\
& outer & $1.64 \pm 0.05^{\mathrm{c}}$ & $1.57 \pm 0.09^{\mathrm{c}}$ & $1.55 \pm 0.05^{\mathrm{c}}$ \\
& means & $1.26 \pm 0.52^{\mathrm{a}}$ & $1.18 \pm 0.48^{\mathrm{a}}$ & $1.18 \pm 0.47^{\mathrm{a}}$ \\
& inner & $0.63 \pm 0.01^{\mathrm{a}}$ & $0.63 \pm 0.01^{\mathrm{a}}$ & $0.64 \pm 0.05^{\mathrm{a}}$ \\
& middle & $1.38 \pm 0.06^{\mathrm{b}}$ & $1.32 \pm 0.10^{\mathrm{b}}$ & $1.30 \pm 0.09^{\mathrm{b}}$ \\
& outer & $1.63 \pm 0.03^{\mathrm{c}}$ & $1.41 \pm 0.14^{\mathrm{b}}$ & $1.41 \pm 0.11^{\mathrm{b}}$ \\
& means & $1.21 \pm 0.52^{\mathrm{a}}$ & $1.12 \pm 0.43^{\mathrm{a}}$ & $1.12 \pm 0.42^{\mathrm{a}}$ \\
\hline
\end{tabular}

Note: Values with the same letter in the same column/raw are not significantly different at the 0.05 probability level

\section{METAXYLEM VESSEL}

Metaxylem vessels were not truly circular but rather elliptical in shape with the radial diameter longer than the tangential. As shown in Table 2, the metaxylem vessels did not vary significantly among ages. Slight decreasing trend was observed from the base toward the top portion and it may be due to the variation in culm wall thickness along the culm height. In the radial direction of culms, the vessels diameter increased significantly from outer to inner in each age-group. The finding was also noticed by Hisham et al. (2006), Liese (1985) and Wang et al. (2011). The vessel with the largest diameter (184.41 $\mu \mathrm{m})$ was observed in the base portion of 1-year-old bamboo culms, while the smallest one $(35.74 \mu \mathrm{m})$ was found in the top portion of the 2 year old culms. The metaxylem vessels were full-grown in the inner and middle zones; this may be attributed to the fact that these zones are mainly functioned for water and nutrient transportation. However, in the outer zone, incomplete developed vascular vessel was observed and no vessels were found in some vascular bundles.

\section{FIBRE DIMENSIONS}

Fibre length The bamboo fibres with tapered ends constitute the sclerenchymatous tissue consisting of vascular bundle caps and isolated strands, playing an important role in the supporting of bamboo self-weight. The fibres are ground in fibre strand and sclerenchyma sheath around the metaxylem vessels and phloem (Grosser \& Liese 1971). As can be seen from Table 3, the fibre length ranged from 1557.31 to $2114.76 \mu \mathrm{m}$ and no significant differences were found among the bamboo ages. The results showed that bamboo fibre length had completed its elongation within 1 year, which was in accordance with the finding of Abd. Latif et al. (1994). From the base to top, the fibre length first increased and then decreased. This may be attributed to the correlation between fibre length and internode length (Liese 1998). According to the Turkey test, no significant difference was observed between the base and middle portions; while the difference between the middle and top portions was significant. The variation trend in fibre length along the bamboo culm height presented in this study was similar to that of Wang et al. (2011) However, Pu and Du (2003) reported that the longer fibre length was located in the bottom culms in Dendrocalamus sinicus. Different variation trends were found among various bamboo species might have resulted from the difference in growth rates among different bamboo species (Abd. Latif \& Mohd. Tamizi 1992). In the radial direction, longer fibres were observed in the middle zones and the longest fibre $(2114.76 \mu \mathrm{m})$ was found in the middle portion of 1 year old bamboo culm. 
TABLE 2. Mean diameter of metaxylem vessel

\begin{tabular}{|c|c|c|c|c|}
\hline Vessel lumen diameter $(\mu \mathrm{m})$ & Zone & 1 years $^{\mathrm{a}}$ & 3 years $^{\mathrm{a}}$ & 5 years $^{\mathrm{a}}$ \\
\hline Base & $\begin{array}{l}\text { Inner } \\
\text { Middle } \\
\text { Outer } \\
\text { Means }\end{array}$ & $\begin{array}{c}184.41 \pm 13.20^{\mathrm{a}} \\
141.03 \pm 5.73^{\mathrm{b}} \\
56.74 \pm 3.44^{\mathrm{c}} \\
127.39 \pm 64.91^{\mathrm{a}}\end{array}$ & $\begin{array}{c}182.80 \pm 14.90^{\mathrm{a}} \\
141.60 \pm 8.03^{\mathrm{b}} \\
58.10 \pm 10.25^{\mathrm{c}} \\
127.50 \pm 63.53^{\mathrm{a}}\end{array}$ & $\begin{array}{c}183.56 \pm 5.36^{\mathrm{a}} \\
146.85 \pm 10.74^{\mathrm{b}} \\
57.02 \pm 4.47^{\mathrm{c}} \\
129.15 \pm 65.11^{\mathrm{a}}\end{array}$ \\
\hline Middle & $\begin{array}{l}\text { Inner } \\
\text { Middle } \\
\text { Outer } \\
\text { Means }\end{array}$ & $\begin{array}{c}180.42 \pm 7.20^{\mathrm{a}} \\
136.91 \pm 5.28^{\mathrm{b}} \\
56.26 \pm 2.19^{\mathrm{c}} \\
124.53 \pm 63.00^{\mathrm{a}}\end{array}$ & $\begin{array}{c}174.02 \pm 11.85^{\mathrm{a}} \\
123.85 \pm 9.36^{\mathrm{b}} \\
44.93 \pm 2.92^{\mathrm{c}} \\
114.27 \pm 65.08^{\mathrm{a}}\end{array}$ & $\begin{array}{c}174.87 \pm 4.91^{\mathrm{a}} \\
126.99 \pm 8.97^{\mathrm{b}} \\
49.99 \pm 3.28^{\mathrm{c}} \\
117.28 \pm 63.00^{\mathrm{a}}\end{array}$ \\
\hline Top & $\begin{array}{l}\text { Inner } \\
\text { Middle } \\
\text { Outer } \\
\text { Means }\end{array}$ & $\begin{array}{c}164.69 \pm 3.36^{\mathrm{a}} \\
124.46 \pm 4.50^{\mathrm{b}} \\
47.77 \pm 0.25^{\mathrm{c}} \\
112.31 \pm 59.40^{\mathrm{a}}\end{array}$ & $\begin{array}{c}149.77 \pm 8.80^{\mathrm{a}} \\
107.87 \pm 6.10^{\mathrm{b}} \\
35.74 \pm 1.26^{\mathrm{c}} \\
97.79 \pm 57.68^{\mathrm{a}}\end{array}$ & $\begin{array}{c}154.11 \pm 5.29^{\mathrm{a}} \\
115.05 \pm 4.57^{\mathrm{b}} \\
44.62 \pm 2.95^{\mathrm{c}} \\
104.59 \pm 55.49^{\mathrm{a}}\end{array}$ \\
\hline
\end{tabular}

Note: Values with the same letter in the same column/row are not significantly different at the 0.05 probability level

Fiber cell wall thickness The fibre cell wall thicknesses increased significantly from 1 to 3 year old and then remained stable (Table 3 ). The thicker wall thickness presented in the outer zone of culms was also reported by Alvin and Murphy (1988), Murphy and Alvin (1997) and Razak et al. (2010). However, the fibre wall thickness of G. scortechinii culms is not affected by ages (Abd. Latif \& Mohd. Tamizi 1992). Variations in fibre cell wall existed in different species might be due to the bamboo properties characterized by its individual characteristics (Liese 1985). Upon height growth, the fibre elongation will cease but the fibre cell wall thickness will continue thicken until maturation (Gan \& Ding 2006). The thickening of fibre cell wall with age might be due to the second wall accumulation and maturation with the deposition of additional lamellae for fibre cell wall (Liese \& Weiner 1996). The thinnest fibre cell wall thickness was found in the middle portion of the 1 year old culms and the largest increase rate in fibre cell wall thickness was observed in the middle portion of culms height from 1 to 3 year old. This is a reflection of early maturation of this portion compared with the base and top portion. In the radial direction, significant increasing trend from inner to outer zone in wall thickness was found in this study.

Fibre lumen diameter The fibre lumen diameter decreased significantly from 1 (ranging from 5.93 to $11.88 \mu \mathrm{m}$ ) to 3 year old (ranging from 2.29 to $5.51 \mu \mathrm{m}$ ). Then a slight decreasing trend was found from 3 to 5 year old culms (ranging from 1.90 to $4.28 \mu \mathrm{m}$ ) (Table 3 ). The smallest lumen diameter was observed in the outer zone in top portion of 5 year old culms. Significant difference in lumen diameters was observed among different heights of 1 and 3 year old ages, while no significant difference were observed among those of 5 year old age. The results in this study meet with the work of Su et al. (2005).

\section{PARENCHYMA DIMENSIONS}

Parenchyma length The parenchyma length did not show significant differences among the ages (Table 4) which shows that the parenchyma length will cease increasing when the height growth of culms is completed. Furthermore, in all the age classes, the length of parenchyma decreased lightly from base to top portion and the middle zone had longer parenchyma cells than that for inner and outer zones. The longest mean length of parenchyma cell $(82.79 \mu \mathrm{m})$ was observed in the middle zone in the base portion of 3 year old culms, while the shortest parenchyma cell (66.82 $\mu \mathrm{m})$ was found in the outer zone in the top portion of 1 year old culms.

Parenchyma cell wall thickness The parenchyma cell wall thickness showed an increasing trend with the increasing of ages (Table 4). Significant increase (from 22.76 to $64.90 \%$ ) was found from 1 to 2 year old, while slight increasing trend was observed from 2 to 3 year old. No uniform variation trend in parenchyma wall thickness from base to top of 1 year-old culms was observed in this study, while an increasing trend was observed from base to top of the 3 year old culms. Hisham et al. (2006) reported that the parenchyma cell wall thickness was not significantly different among ages and almost all parenchyma dimensions were smaller at younger age. Those results were supported by Abd Latif et al. (1993) and Razak et al. (2009). The cell wall thickness of parenchyma cells increased insignificantly from inner to middle zone and then significantly increased to outer zone. The largest cell wall thickness of parenchyma $(3.95 \mu \mathrm{m})$ was observed in the outer zone in the top portion of 5 year old.

Parenchyma lumen diameter Difference in lumen diameter of parenchyma was insignificant among the age groups, heights and zones. The highest lumen diameter $(31.07 \mu \mathrm{m})$ of parenchyma cell was located in the inner zone in the base portion of 1 year old culms, while the lowest lumen diameter $(13.71 \mu \mathrm{m})$ was observed in the outer zone in the top portion of 5 year old culms. However, Razak et al. $(2009,2006)$ reported that the middle portion of $G$. scorechinii and B. vulgaris bamboos had larger lumen diameter compared with the base and top portions. 
TABLE 3. Mean fibre dimensions

\begin{tabular}{|c|c|c|c|c|}
\hline Fibre length $(\mu \mathrm{m})$ & Zone & 1 years $^{\mathrm{a}}$ & 3 years $^{\mathrm{a}}$ & 5 years $^{\mathrm{a}}$ \\
\hline \multirow[t]{4}{*}{ Base } & Inner & $1652.32 \pm 105.32^{\mathrm{a}}$ & $1753.80 \pm 34.55^{\mathrm{a}}$ & $1631.79 \pm 56.59^{\mathrm{a}}$ \\
\hline & Middle & $1722.57 \pm 98.17^{\mathrm{a}}$ & $1863.15 \pm 35.44^{\mathrm{ab}}$ & $1730.13 \pm 86.05^{\mathrm{a}}$ \\
\hline & Outer & $1672.83 \pm 68.93^{\mathrm{a}}$ & $1812.74 \pm 61.69^{b}$ & $1728.06 \pm 52.46^{\mathrm{a}}$ \\
\hline & Means & $1682.57 \pm 139.99^{a}$ & $1809.90 \pm 62.33^{\mathrm{a}}$ & $1696.66 \pm 77.07^{\mathrm{a}}$ \\
\hline \multirow[t]{4}{*}{ Middle } & Inner & $1816.91 \pm 109.33^{\mathrm{a}}$ & $1769.98 \pm 97.31^{\mathrm{a}}$ & $1645.52 \pm 60.09^{\mathrm{a}}$ \\
\hline & Middle & $2114.76 \pm 93.40^{\mathrm{b}}$ & $1979.70 \pm 88.08^{\mathrm{a}}$ & $1777.62 \pm 61.89 \mathrm{a}^{\mathrm{b}}$ \\
\hline & Outer & $1914.57 \pm 101.60^{\mathrm{ab}}$ & $1794.31 \pm 73.16^{\mathrm{a}}$ & $1701.55 \pm 12.81^{\mathrm{b}}$ \\
\hline & Means & $1948.74 \pm 185.00^{\mathrm{b}}$ & $1848.00 \pm 154.15^{\mathrm{a}}$ & $1708.23 \pm 72.60^{\mathrm{a}}$ \\
\hline \multirow[t]{4}{*}{ Top } & Inner & $1678.28 \pm 125.50^{\mathrm{a}}$ & $1590.31 \pm 52.88^{\mathrm{a}}$ & $1611.77 \pm 60.94^{\mathrm{a}}$ \\
\hline & Middle & $1984.68 \pm 119.63^{b}$ & $1649.66 \pm 103.19^{\mathrm{a}}$ & $1656.49 \pm 56.26^{\mathrm{a}}$ \\
\hline & Outer & $1755.49 \pm 121.77^{\mathrm{ab}}$ & $1611.17 \pm 189.28^{\mathrm{a}}$ & $1557.31 \pm 75.09^{\mathrm{a}}$ \\
\hline & Means & $1806.15 \pm 175.25^{\mathrm{ab}}$ & $1617.04 \pm 167.52^{b}$ & $1608.52 \pm 112.10^{\mathrm{b}}$ \\
\hline Fibre cell wall thickness $(\mu \mathrm{m})$ & Zone & 1 years $^{a}$ & 3 years $^{b}$ & 5 years $^{\mathrm{b}}$ \\
\hline \multirow[t]{4}{*}{ Base } & Inner & $3.74 \pm 0.33^{\mathrm{a}}$ & $9.26 \pm 0.66^{\mathrm{a}}$ & $9.62 \pm 0.64^{\mathrm{a}}$ \\
\hline & Middle & $3.94 \pm 0.41^{\mathrm{a}}$ & $10.70 \pm 0.73^{\mathrm{ab}}$ & $10.20 \pm 1.19^{\mathrm{a}}$ \\
\hline & Outer & $5.17 \pm 0.20^{\mathrm{b}}$ & $11.57 \pm 0.36^{\mathrm{b}}$ & $10.67 \pm 0.73^{\mathrm{a}}$ \\
\hline & Means & $4.28 \pm 0.96^{\mathrm{a}}$ & $10.51 \pm 0.76^{\mathrm{a}}$ & $10.17 \pm 0.52^{\mathrm{a}}$ \\
\hline \multirow[t]{4}{*}{ Middle } & Inner & $2.93 \pm 0.43^{\mathrm{a}}$ & $9.97 \pm 0.83^{\mathrm{a}}$ & $9.92 \pm 0.81^{\mathrm{a}}$ \\
\hline & Middle & $3.18 \pm 0.46^{\mathrm{a}}$ & $11.38 \pm 0.23^{\mathrm{a}}$ & $10.81 \pm 0.87^{\mathrm{a}}$ \\
\hline & Outer & $5.34 \pm 0.54^{\mathrm{b}}$ & $11.54 \pm 0.78^{\mathrm{a}}$ & $11.47 \pm 0.94^{\mathrm{a}}$ \\
\hline & Means & $3.82 \pm 1.02^{\mathrm{a}}$ & $10.96 \pm 0.86^{\mathrm{a}}$ & $10.74 \pm 0.78^{a}$ \\
\hline \multirow[t]{4}{*}{ Top } & Inner & $3.20 \pm 0.37^{\mathrm{a}}$ & $9.68 \pm 0.20^{\mathrm{a}}$ & $9.65 \pm 0.81^{\mathrm{a}}$ \\
\hline & Middle & $3.19 \pm 0.27^{\mathrm{a}}$ & $10.26 \pm 0.29^{\mathrm{ab}}$ & $10.46 \pm 0.86^{b}$ \\
\hline & Outer & $5.09 \pm 0.65^{b}$ & $10.60 \pm 0.66^{b}$ & $10.55 \pm 0.94^{b}$ \\
\hline & Means & $3.83 \pm 0.89^{\mathrm{a}}$ & $10.18 \pm 0.47^{\mathrm{a}}$ & $10.22 \pm 0.50^{\mathrm{a}}$ \\
\hline Fibre lumen diameter $(\mu \mathrm{m})$ & Zone & 1 years $^{\mathrm{a}}$ & 3 years $^{b}$ & 5 years $^{b}$ \\
\hline \multirow[t]{4}{*}{ Base } & Inner & $10.94 \pm 0.51^{\mathrm{ab}}$ & $5.51 \pm 0.41^{\mathrm{a}}$ & $4.28 \pm 0.47^{\mathrm{a}}$ \\
\hline & Middle & $11.86 \pm 0.40^{\mathrm{a}}$ & $5.34 \pm 0.67^{\mathrm{a}}$ & $3.95 \pm 0.33^{\mathrm{a}}$ \\
\hline & Outer & $9.91 \pm 0.69^{b}$ & $2.79 \pm 0.88^{b}$ & $2.52 \pm 0.30^{\mathrm{a}}$ \\
\hline & Means & $10.90 \pm 0.98^{a}$ & $4.55 \pm 1.12^{\mathrm{a}}$ & $3.58 \pm 0.93^{\mathrm{a}}$ \\
\hline \multirow[t]{4}{*}{ Middle } & Inner & $11.88 \pm 1.61^{\mathrm{a}}$ & $3.53 \pm 0.47^{\mathrm{a}}$ & $2.31 \pm 0.45^{\mathrm{a}}$ \\
\hline & Middle & $11.82 \pm 1.52^{\mathrm{a}}$ & $4.06 \pm 0.86^{\mathrm{a}}$ & $2.28 \pm 0.33^{\mathrm{a}}$ \\
\hline & Outer & $6.35 \pm 0.79^{b}$ & $2.02 \pm 0.25^{\mathrm{a}}$ & $1.92 \pm 0.22^{\mathrm{a}}$ \\
\hline & Means & $10.02 \pm 1.01^{\mathrm{a}}$ & $3.20 \pm 0.75^{\mathrm{a}}$ & $2.17 \pm 0.22^{b}$ \\
\hline \multirow[t]{4}{*}{ Top } & Inner & $11.01 \pm 1.19^{\mathrm{a}}$ & $2.61 \pm 0.17^{\mathrm{a}}$ & $2.01 \pm 0.12^{\mathrm{a}}$ \\
\hline & Middle & $11.04 \pm 0.71^{\mathrm{a}}$ & $2.84 \pm 0.35^{\mathrm{a}}$ & $1.99 \pm 0.04^{\mathrm{a}}$ \\
\hline & Outer & $5.93 \pm 0.67^{\mathrm{b}}$ & $2.29 \pm 0.34^{\mathrm{a}}$ & $1.90 \pm 0.07^{\mathrm{a}}$ \\
\hline & Means & $9.33 \pm 0.84^{\mathrm{a}}$ & $2.58 \pm 0.27^{\mathrm{a}}$ & $1.97 \pm 0.06^{\mathrm{b}}$ \\
\hline
\end{tabular}

Note: Values with the same letter in the same column/row are not significantly different at the 0.05 probability level

\section{CONCLUSION}

The vascular bundles, fibre and parenchyma of B. rigida analyzed in this experiment were affected insignificantly by ages. Vascular size and parenchyma lumen diameter decreased with the increasing of age. With age increment, significant differences between 1 and 3 year old culms in fibre cell wall thickness, lumen diameter and parenchyma cell wall thickness were found in this study. The vascular bundles frequency in all the age classes and parenchyma cell wall thickness of 3 and 5 year old culms showed insignificant increase with height. However, the vascular bundle size, vessel lumen diameter, fibre lumen diameter, parenchyma length and lumen decreased with height.
In addition, the fibre length reached the longest in the middle portion and the fibre cell wall thickness in the 3 and 5 year old culms reached the largest in the middle portion. In the radial direction of culm wall thickness, the vascular bundles and parenchyma lumen diameter varied significantly among different zones. The larger vascular bundles and parenchyma lumen diameter were located in the middle and the longer fibre and parenchyma were also found in the middle zone and the denser vascular and thicker fibre and parenchyma cell wall thickness were observed in the outer zone. Furthermore, the wall thicknesses of fibre and parenchyma increased significantly from 1 to 3 year old, showing that there is a maturing progress for these ages. 
TABLE 4. Mean parenchyma dimensions

\begin{tabular}{|c|c|c|c|c|}
\hline Parenchyma length $(\mu \mathrm{m})$ & Zone & 1 years $^{\mathrm{a}}$ & 3 years $^{\mathrm{a}}$ & 5 years $^{\mathrm{a}}$ \\
\hline \multirow[t]{4}{*}{ Base } & Inner & $86.17 \pm 5.87^{\mathrm{a}}$ & $82.01 \pm 2.28^{\mathrm{a}}$ & $81.25 \pm 7.07^{\mathrm{a}}$ \\
\hline & Middle & $81.52 \pm 3.16^{\mathrm{a}}$ & $82.79 \pm 5.31^{\mathrm{a}}$ & $82.79 \pm 4.14^{\mathrm{a}}$ \\
\hline & Outer & $77.17 \pm 3.10^{\mathrm{a}}$ & $78.16 \pm 1.27^{\mathrm{a}}$ & $79.36 \pm 3.50^{\mathrm{a}}$ \\
\hline & Means & $81.62 \pm 4.50^{\mathrm{a}}$ & $80.98 \pm 2.48^{\mathrm{a}}$ & $81.13 \pm 1.72^{\mathrm{a}}$ \\
\hline \multirow[t]{4}{*}{ Middle } & Inner & $84.00 \pm 1.82^{\mathrm{a}}$ & $76.32 \pm 3.99^{a}$ & $78.62 \pm 0.56^{\mathrm{a}}$ \\
\hline & Middle & $84.85 \pm 2.60^{\mathrm{a}}$ & $78.73 \pm 2.07^{\mathrm{a}}$ & $79.49 \pm 3.90^{\mathrm{a}}$ \\
\hline & Outer & $73.53 \pm 3.86^{b}$ & $76.16 \pm 8.03^{a}$ & $75.03 \pm 2.08^{\mathrm{a}}$ \\
\hline & Means & $80.79 \pm 6.30^{\mathrm{a}}$ & $77.07 \pm 1.44^{\mathrm{a}}$ & $77.71 \pm 2.36^{\mathrm{a}}$ \\
\hline \multirow[t]{4}{*}{ Top } & Inner & $80.36 \pm 6.76^{\mathrm{a}}$ & $76.46 \pm 2.81^{\mathrm{a}}$ & $77.12 \pm 2.11^{\mathrm{a}}$ \\
\hline & Middle & $83.47 \pm 6.60^{\mathrm{a}}$ & $78.46 \pm 3.32^{\mathrm{a}}$ & $78.00 \pm 2.73^{a}$ \\
\hline & Outer & $66.82 \pm 1.73^{b}$ & $75.19 \pm 2.14^{\mathrm{a}}$ & $75.60 \pm 2.83^{\mathrm{a}}$ \\
\hline & Means & $76.88 \pm 8.85^{\mathrm{a}}$ & $76.70 \pm 1.65^{\mathrm{a}}$ & $76.91 \pm 1.21^{\mathrm{a}}$ \\
\hline Parenchyma cell wall thickness ( $\mu \mathrm{m})$ & Zone & 1 years $^{\mathrm{a}}$ & 3 years $^{\text {b }}$ & 5 years $^{b}$ \\
\hline \multirow[t]{4}{*}{ Base } & Inner & $2.04 \pm 0.18^{\mathrm{a}}$ & $2.71 \pm 0.72^{\mathrm{a}}$ & $2.83 \pm 0.25^{\mathrm{a}}$ \\
\hline & Middle & $2.32 \pm 0.25^{\mathrm{a}}$ & $2.80 \pm 0.37^{\mathrm{a}}$ & $3.10 \pm 0.27^{\mathrm{a}}$ \\
\hline & Outer & $2.93 \pm 0.14^{\mathrm{a}}$ & $3.69 \pm 0.48^{a}$ & $3.32 \pm 0.67^{\mathrm{a}}$ \\
\hline & Means & $2.42 \pm 0.45^{\mathrm{a}}$ & $3.06 \pm 0.54^{\mathrm{a}}$ & $3.08 \pm 0.25^{\mathrm{a}}$ \\
\hline \multirow[t]{4}{*}{ Middle } & Inner & $2.23 \pm 0.65^{\mathrm{a}}$ & $2.84 \pm 0.50^{\mathrm{a}}$ & $3.24 \pm 0.30^{\mathrm{a}}$ \\
\hline & Middle & $2.40 \pm 0.51^{\mathrm{a}}$ & $2.92 \pm 0.72^{\mathrm{a}}$ & $3.34 \pm 0.38^{\mathrm{a}}$ \\
\hline & Outer & $2.75 \pm 0.44^{\mathrm{a}}$ & $3.32 \pm 0.46^{\mathrm{a}}$ & $3.58 \pm 0.51^{\mathrm{a}}$ \\
\hline & Means & $2.46 \pm 0.27 \mathrm{a}$ & $3.02 \pm 0.26^{\mathrm{a}}$ & $3.38 \pm 1.17^{\mathrm{ab}}$ \\
\hline \multirow[t]{4}{*}{ Top } & Inner & $1.89 \pm 0.19^{a}$ & $3.28 \pm 0.57^{\mathrm{a}}$ & $3.70 \pm 0.20^{\mathrm{a}}$ \\
\hline & Middle & $2.01 \pm 0.27^{\mathrm{a}}$ & $3.45 \pm 0.45^{\mathrm{a}}$ & $3.76 \pm 0.45^{\mathrm{a}}$ \\
\hline & Outer & $2.33 \pm 0.28^{\mathrm{a}}$ & $3.55 \pm 0.53^{\mathrm{a}}$ & $3.95 \pm 0.46^{\mathrm{a}}$ \\
\hline & Means & $2.08 \pm 0.23^{\mathrm{a}}$ & $3.43 \pm 0.14^{\mathrm{a}}$ & $3.80 \pm 0.16^{\mathrm{b}}$ \\
\hline Parenchyma lumen diameter $(\mu \mathrm{m})$ & Zone & 1 years $^{\mathrm{a}}$ & 3 years $^{\mathrm{a}}$ & 5 years $^{\mathrm{a}}$ \\
\hline \multirow[t]{4}{*}{ Base } & Inner & $31.07 \pm 1.81^{\mathrm{a}}$ & $27.98 \pm 1.59^{\mathrm{a}}$ & $28.09 \pm 1.32^{\mathrm{a}}$ \\
\hline & Middle & $27.30 \pm 1.62^{\mathrm{a}}$ & $25.28 \pm 2.01^{\mathrm{a}}$ & $25.07 \pm 0.46^{b}$ \\
\hline & Outer & $24.91 \pm 1.30^{\mathrm{a}}$ & $17.03 \pm 1.13^{\mathrm{b}}$ & $20.01 \pm 0.69^{c}$ \\
\hline & Means & $27.76 \pm 3.11^{\mathrm{a}}$ & $23.43 \pm 5.70^{\mathrm{a}}$ & $24.39 \pm 4.08^{\mathrm{a}}$ \\
\hline \multirow[t]{4}{*}{ Middle } & Inner & $30.32 \pm 1.19^{\mathrm{a}}$ & $26.97 \pm 1.93^{\mathrm{a}}$ & $26.39 \pm 0.69^{a}$ \\
\hline & Middle & $27.47 \pm 1.08^{\mathrm{b}}$ & $23.12 \pm 1.07^{\mathrm{b}}$ & $21.76 \pm 1.44^{b}$ \\
\hline & Outer & $21.84 \pm 1.31^{\mathrm{c}}$ & $17.13 \pm 1.16^{\mathrm{c}}$ & $15.54 \pm 1.65^{\mathrm{c}}$ \\
\hline & Means & $26.55 \pm 4.32^{\mathrm{a}}$ & $22.41 \pm 5.00^{\mathrm{a}}$ & $21.23 \pm 5.44^{\mathrm{a}}$ \\
\hline \multirow[t]{4}{*}{ Top } & Inner & $26.66 \pm 2.76^{a}$ & $23.06 \pm 0.84^{\mathrm{a}}$ & $21.23 \pm 1.99^{a}$ \\
\hline & Middle & $24.89 \pm 1.34^{\mathrm{a}}$ & $19.34 \pm 1.15^{\mathrm{b}}$ & $18.53 \pm 2.64^{\mathrm{a}}$ \\
\hline & Outer & $19.03 \pm 1.18^{\mathrm{b}}$ & $14.82 \pm 0.65^{\mathrm{c}}$ & $13.71 \pm 1.47^{\mathrm{b}}$ \\
\hline & Means & $23.53 \pm 4.00^{\mathrm{a}}$ & $19.07 \pm 4.13^{\mathrm{a}}$ & $17.82 \pm 3.81^{\mathrm{a}}$ \\
\hline
\end{tabular}

Note: Values with the same letter in the same column/row are not significantly different at the 0.05 probability level

\section{ACKNOWLEDGMENTS}

The present study was financially supported by Key Laboratory of Wood Industry and Furniture Engineering, Sichuan Provincial Colleges and Universities and Cultivation Project for Promoting Excellent in Research for Master Degrees, Sichuan Agriculture University.

\section{REFERENCES}

Abd. Latif, M. 2001. Anatomical features of Bambusa vulgaris and Gigantochloa scortechinii from four harvesting sites in Peninsular Malaysia. Journal of Tropical Forest Products 7(1): 10-28.
Abd.Latif, M. \& Mohd. Tamizi, M. 1992. Variation in anatomical properties of three Malaysian bamboos from natural stands. Journal of Tropical Science 5(1): 90-96.

Abd. Latif, M., Khoo, K.C., Jamaludin, K. \& Abd. Jalil, H.A. 1994. Fiber morphology and chemical properties of Gigantochloa scortechinii.Journal of Tropical Forest Science 6: 397-407.

Abd. Latif, M., Ashaari Hj., A., Jamaludin, K. \& Mohd. Zin, J. 1993. Effects of anatomical characteristics on the physical and mechanical properties of Bambusa blumeana. Journal of Tropical Forestry Science 6(2): 159-170.

Abd. Latif, M., Wan Tarmeze, W.A. \& Fauzidah, A. 1990. Anatomical features and mechanical properties of three 
Malaysia bamboos. Journal of Tropical Forest Science 2(3): 227-234

Abd. Razak, O., Abd. Latif, M., Liese, W. \& Norini, H. 1995. Planting and utilization of bamboo in Peninsular Malaysia. FRIM Research Pamplet No. 118.

Alvin, K.L. \& Murphy, R.J. 1988. Variation in fiber and parenchyma wall thickness in culms of the bamboo Sinobambusa tootsik. IAWA Journal 9(4): 353-361.

Espiloy, Z. 1992. Properties affecting bamboo utilization: Bamboo and its use. International Symposium and Industrial Use of Bamboo. pp. 139-142.

Espiloy, Z.B. 1987. Physico-mechanical properties and anatomical relationship of some Philippines bamboos. In Recent Research on Bamboos, edited by Rao, A.N., Dhanarajan, G. \& Sastry, C.B. International Workshop on Bamboo. 6-14 October, 1985. Hangzhou, China. pp. 257-265.

Gan, X.H. \& Ding, Y.L. 2006. Investigation on the variation of fiber wall in Phyllostachys edulis culms. Forest Research 19(4): 457-462.

Grosser, D. \& Liese, W. 1971. On the anatomy of Asian bamboos, with special reference to their vascular bundles. Wood Science and Technology 5(4): 290-312.

Hisham, H.N., Othman, S., Rokiah, H., Abd. Latif, M., Ani, S. \& Mohd. Tamizi, M. 2006. Characterization of bamboo Gigantochloa scortechinii at different ages. Journal of Tropical Forest Science 18(4): 236-242.

Kelemwork, S. 2009. Effects of anatomical characteristics of Ethiopian Lowland bamboo on physical and mechanical properties. Chinese Forestry Science and Technology 18(3): 32-43.

Liese, W. 1998. The anatomy of bamboo culms. Beijing: INBAR Technical Report 18: 130-135.

Liese, W. 1985. Anatomy and properties of bamboo. In Bamboos, Biology, Silvics, Properties, Utilization, edited by Liese, W. \& Deutsche Geselschaft fiir Technische Zusanimenarbeit. Eschborn: Deutsche Geselschaft fiir Technische Zusanimenarbeit (GTZ). pp. 13-126.

Liese, W.\& Weiner, G. 1996. Ageing of bamboo culms: A review. Wood Science and Technology 30(2): 77-89.

Murphy, R.J. \& Alvin, K.L. 1997. Fiber maturation in the bamboo Gigantochloa scortechinii. IAWA Journal 18(2): 147-156.
Parameswaran, N. \& Liese, W. 1976. On the fine structure of bamboo fibres. Wood Science and Technology 10(4): 231-246.

$\mathrm{Pu}$, X.L. \& Du, F. 2003. Study of fiber morphology and its variation law of Dendrocalamus sinicus. Yunnan Forestry Science and Technology 102: 1-4.

Razak, W. 1998. Effect of selected preservatives on the durability of Gigantochloa scortechinii. PhD thesis, University of London (unpublished)

Razak, W., Mohd. Tamizi, M., Othman, S., Aminuddin, M., Affendy, H. \& Izyan, K. 2010. Anatomical and physical properties of cultivated two- and four-year-old Bambusa vulgaris. Sains Malaysiana 39(4): 571-579.

Razak, W., Mohamed, A., Mustafa, M.T. \& Hassan, A. 2009 Physical characteristics and anatomical properties of cultivated bamboo (Bambusa vulgaris Schrad.) culms. Journal of Biological Sciences 9(7): 753-759.

Razak, W., Mohamad, A., Hashim, W.S., Awang Ahmad, M.Y \& Janshah, M. 2006. Physical characteristics, anatomy and properties of managed Gigantochloa scortechinii natural bamboo stands. Journal of Plant Sciences 1(2): 144-153.

Su, W.H., Gu, X.P., Ma, L.F., Wu, X.L. \& Yue, J.J. 2005 Study on fiber forms and tissue measurements of Bambusa wenchouensis wood. Forest Research 18(3): 250-254.

Wangaard,F.F. \& Woodson, G.E. 1973. Fiber length-fiber strength interrelationship for slash pine and its effect on pulp-sheet properties. Wood Science 5(3): 235-240.

Wang, S.G., Pu, X.L., Ding, Y.L., Wan, X.C. \& Lin, S.Y. 2011. Anatomical and chemical properties of Fargesia yunnanensis. Journal of Tropical Forest Science 23(1): 73-81.

College of Forestry, Sichuan Agricultural University

Yaan, Sichuan 625014

China

*Corresponding author; email: qijinqiu2005@aliyun.com

Received: 8 November 2013

Accepted: 30 June 2014 